\title{
KULTIVASI HIDROPONIK SEBAGAI MANAJEMEN NUTRISI DAN PENINGKATAN PRODUKTIVITAS KELUARGA PEKERJA ESENSIAL PRASEJAHTERA DI MINASAUPA
}

\author{
Andi Fitria Idham 1), Andi Muhammad Rayyan Eka Putra²), Jauharah Rahadatul Aisy3), \\ Muhammad Ayatullah Khumaeni'), Asrina ${ }^{1)}$ \\ 1)Program Studi IImu Keperawatan, Fakultas Keperawatan, Universitas Hasanuddin, Kota Makassar, Sulawesi Selatan, \\ Indonesia \\ 2)Program Studi Teknik Informatika, Fakultas Teknik, Universitas Hasanuddin, Kota Makassar, Sulawesi Selatan, \\ Indonesia \\ ${ }^{3)}$ Program Studi Agroteknologi, Fakultas Pertanian, Universitas Hasanuddin, Kota Makassar, Sulawesi Selatan, \\ Indonesia \\ Corresponding author: Andi Fitria Idham \\ E-mail : andifitriaidham@gmail.com
}

Diterima 29 Juli 2021, Direvisi 31 Juli 2021, Disetujui 01 Agustus 2021

\begin{abstract}
ABSTRAK
Pandemi telah membawa dampak yang sangat besar pada seluruh lapisan masyarakat, khususnya pada individu yang kurang beruntung. Pekerja esensial prasejahtera adalah individu-individu yang paling menderita akibat pandemi, mereka sangat kesulitan untuk memenuhi kebutuhan pokok keluarganya seperti makanan, pakaian, dan tempat tinggal yang layak. Ini pada akhirnya berakibat pada ketidakmampuan untuk memberi makanan yang layak dengan kandungan nutrisi maksimum pada keluarganya. Ini memicu tim untuk menawarkan solusi pada permasalahan komunitas ini. Hidroponik merupakan salah satu cara kultivasi tanaman, cara ini masih jarang diketahui oleh masyarakat prasejahtera akibat rendahnya tingkat edukasi mereka. Kultivasi hidroponik ini dapat menjadi solusi bagi penderitaan mereka. Kultivasi hidroponik dapat menawarkan komunitas ini tanaman dengan nutrisi tinggi yang tidak membutuhkan lahan yang luas dan memerlukan modal yang lebih sedikit. Tanaman bernutrisi tinggi ini dapat digunakan untuk konsumsi lokal dalam keluarganya dan dapat dijual kepada pihak luar untuk meningkatkan produktivitas. Pada kegiatan ini, masyarakat mitra akan diberi edukasi mengenai kesehatan dasar, manajemen nutrisi, dan pendampingan kultivasi hidroponik. Kegiatan ini telah berhasil meningkatkan pengetahuan masyarakat mengenai kesehatan dasar dan nutrisi, dan telah berhasil meningkatkan produktivitas masyarakat melalui kultivasi hidroponik hingga satu kali panen.
\end{abstract}

Kata kunci: hidroponik; nutrisi; manajemen nutrisi

\begin{abstract}
Pandemic already bring huge impact on all layer of society, especially to those individual who having no privilege. Underprivileged essential workers were those individual who suffer the most caused by this pandemic, they were struggling to fulfil their family's basic needs such as food, clothes, and proper housing. This resulted into their unability to give proper food with maximum nutrition to their family. This trigger the team to propose solution for this community problem. Hydroponic is one of the cultivation way of plants, this way of cultivating rarely known by underprivileged community caused by their lack of education. Meanwhile this hydroponic could be the answer of their suffering. This hydroponic cultivation could provide this community high nutrition plants that does not require them a huge land and less capital needed. This high nutrition plants could being used for local consumption in their community and could being sold to outsiders to boost productivity. In this program, partner community will given education about basic health, nutrition management, and accompaniment on hydroponic cultivation. This program has successfully increase community's knowledge about basic health and nutrition, and have succeeded boost community's productivity through hydroponic cultivation in one time harvest.
\end{abstract}

Keywords: hydroponic; nutrition; nutrition management

\section{PENDAHULUAN}

Pandemi COVID-19 memberikan dampak yang cukup besar pada pekerja esensial prasejahtera dan keluarganya dari aspek ekonomi. Wawancara yang kami lakukan kepada Ibu Yuli sebagai perwakilan mitra kelompok ibu-ibu yang merupakan istri pekerja esensial prasejahtera, secara garis besar terdapat dua permasalahan yang dihadapi. Permasalahan pertama, tidak maksimalnya 
pengaturan gizi dalam keluarga yang selanjutnya kami translasikan dengan buruknya manajemen gizi dalam keluarga. Permasalahan kedua yaitu tidak maksimalnya pendapatan keluarga karena sumber penghasilan hanya berasal dari kepala keluarga dan hal ini berarti tingkat produktivitas keluarga sangat rendah.

Saat perwakilan mitra ditanya lebih lanjut mengenai bahan makanan yang beliau dan keluarganya beli untuk konsumsi seharihari, rupanya mereka hanya terfokus untuk membeli bahan makanan pokok seperti beras dan lauk dengan harga terjangkau seperti tahu, tempe, maupun mie instan. Hal ini pada akhirnya berakibat pada rendahnya konsumsi sayuran organik yang bergizi. Permasalahan ini sejalan dengan penelitian mengenai faktor risiko kurang konsumsi buah dan sayur pada anak usia sekolah dasar yang berhubungan dengan tingkat kesejahteraan keluarga rendah, ketersediaan buah dan sayur di rumah kurang, dan dukungan yang kurang dari orang tua (Hidayati et al., 2017).

Saat kami bertanya kepada perwakilan mitra mengenai penghasilan keluarganya, beliau mengatakan bahwa satu-satunya sumber penghasilan dalam keluarga berasal dari suaminya. Suami ibu Yuli bekerja sebagai supir angkutan umum dengan kategori prasejahtera, sedang beliau sebagai istri tidak bekerja dan hanya bertugas mengerjakan urusan rumah. Hal yang diungkapkan oleh mitra ini sesuai dengan penelitian yang menyatakan bahwa seorang istri pada umumnya bertugas mengerjakan urusan rumah termasuk menyiapkan makanan anggota keluarganya. Mitra juga mengungkapkan bahwa akibat rendahnya pemasukan keluarga, mereka mengalami kesulitan untuk memenuhi kebutuhan sehari-harinya, utamanya pada masa pandemi. Pernyataan ini sesuai dengan jurnal yang menyatakan bahwa masalah utama yang dihadapi keluarga prasejahtera adalah rendahnya kemampuan finansial keluarga untuk memenuhi kebutuhan hidupnya, baik itu pangan, sandang, dan papan (Putri \& Lestari, 2015; Zubaidi et al., 2020).

Setelah berdiskusi bersama mitra, tim sepakat bahwa kedua permasalahan diatas merupakan penyebab utama buruknya manajemen nutrisi dan produktivitas dalam keluarganya. Atas dasar hal tersebut, kami tergugah untuk menawarkan solusi berupa kultivasi hidroponik kepada mereka. Kultivasi hidroponik ini menawarkan tanaman yang mudah diperbaharui tanpa tergantung kondisi lahan dan musim, pertumbuhan dan kualitas panennya dapat diatur, hemat tenaga kerja, produk yang dihasilkan bersih dan lebih higienis, hemat air dan pupuk (aman untuk kelestarian lingkungan), serta jangka waktu pertumbuhan tanamannya lebih singkat. Dari perspektif ekonomi, penggunaan media tanam hidroponik sangat menguntungkan dari biaya operasionalnya, sebab tidak menggunakan listrik untuk memberikan larutan nutrisi hidroponik pada tanaman (Masduki, 2018; Nurlaili et al., 2019).

Melalui rangkaian program kultivasi hidroponik, diharapkan masyarakat mitra dapat memperbaiki manajemen nutrisi dalam keluarganya, sehubungan dengan masalah kekurangan gizi dalam komunitasnya. Kemudian, program ini juga diharapkan dapat meningkatkan produktivitas masyarakat mitra melalui penjualan sayuran yang merupakan hasil dari kultivasi hidroponiknya.

\section{METODE}

Program pengabdian kepada masyarakat ini telah dilaksanakan di Kelurahan Minasaupa, Kecamatan Rappocini, Kota Makassar, Sulawesi Selatan. Mitra dalam kegiatan pengabdian ini berjumlah 15 orang yang merupakan lbu-ibu keluarga dari pekerja esensial prasejahtera (didominasi oleh supir angkutan umum). Ada beberapa tahapan yang dilaksanakan dalam kegiatan pengabdian ini, yaitu:

1. Persiapan media tanam hidroponik dan kebutuhan lainnya.

2. Sosialisasi kegiatan yang dilaksanakan secara daring.

3. Pemberian materi pengantar kesehatan yang mencakup edukasi dasar kesehatan dan pemaparan informasi kesehatan umum mengenai covid-19 dan adaptasi kebiasaan baru.

4. Edukasi mengenai nutrisi dan pengenalan sayuran bergizi.

5. Pemberian evaluasi untuk mengetahui pemahaman masyarakat mitra mengenai materi.

6. Edukasi kultivasi hidroponik, mencakup materi lengkap kultivasi hidroponik dan praktiknya.

7. Pendampingan kultivasi hidroponik hingga tahap panen.

\section{HASIL DAN PEMBAHASAN}

Tahap awal dari pelaksanaan program ini adalah persiapan media tanam hidroponik dan kebutuhan lainnya. Pada tahapan ini tim dibantu praktisi hidroponik mempersiapkan media tanam hidroponik berupa pipa hidroponik lengkap dengan rangka dan pompa airnya. Untuk memastikan keamanan dan estetika media tanam, tim dibantu praktisi hidroponik juga memasang atap berupa seng transparan 
dan pagar penghalang yang terbuat dari kawat kasa. Selanjutnya tim juga mengadakan berbagai kebutuhan lainnya seperti bibit, nutrisi tanaman, spanduk, dan kebutuhan lainnya. Seluruh kebutuhan ini selanjutnya dibawa ke lokasi pengabdian yang terletak didekat rumah mitra.

Pada tahapan kedua tim melakukan sosialisasi mengenai kegiatan kepada masyarakat mitra. Tahapan ini dihadiri oleh seluruh anggota tim dan perwakilan dari masyarakat mitra. Adapun hal yang dipaparkan oleh tim pada saat sosialisasi yaitu detail waktu pelaksanaan kegiatan, tujuan kegiatan, dan sesi tanya jawab bersama mitra. Pada tahapan ini mitra sangat antusias memberi pertanyaan yang berhubungan dengan pelaksanaan kegiatan kepada tim. Kegiatan ini dilakukan secara daring melalui platform zoom meeting pada tanggal 5 Juni 2021. Adapun dokumentasi pelaksanaan sosialisasi kegiatan via zoom meeting dapat dilihat pada gambar 1 .

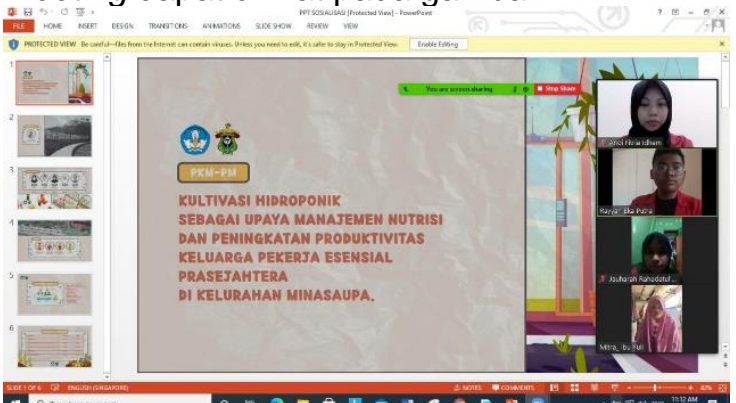

Gambar 1. Sosialisasi Kegiatan via zoom meeting

Pada tahapan ketiga dilakukan pemberian materi pengantar kesehatan. Pada bagian pertama tahapan ketiga ini tim memberikan materi edukasi kesehatan dasar yaitu konsep sehat-sakit, penanganan penyakit ringan, gejala klinis dan pencegahan penyakit, pengenalan mengenai virus corona, dan cara mencuci tangan tujuh langkah sesuai dengan standar WHO. Tahapan ini dilaksanakan pada tanggal 13 Juni 2021 di halaman Masjid AlFurqan Kelurahan Minasaupa dan dihadiri oleh anggota tim beserta masyarakat mitra. Kegiatan dilaksanakan dengan tetap menerapkan protokol kesehatan di lokasi kegiatan. Adapun dokumentasi pemberian materi pengantar kesehatan yang dilaksanakan secara luring dapat dilihat pada gambar 2.

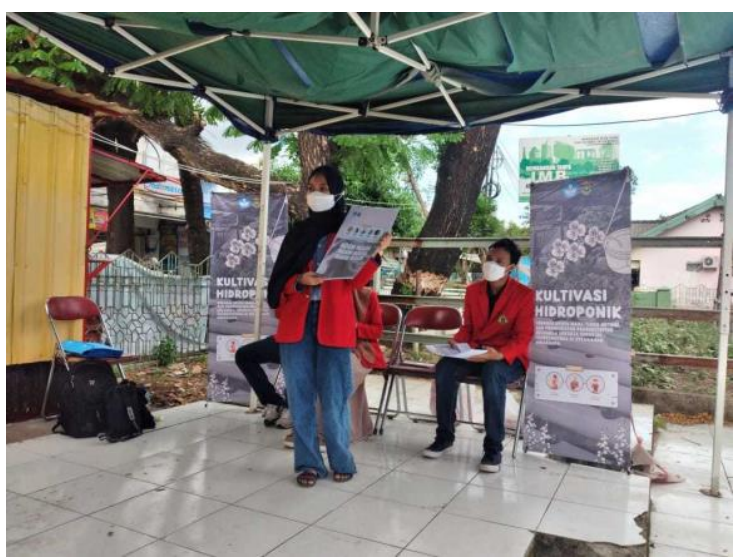

Gambar 2. Pemberian materi pengantar kesehatan (foto diambil sebelum penerapan PPKM)

Pada tahapan keempat telah dilaksanakan pemberian edukasi mengenai nutrisi dan pengenalan sayuran bergizi. Pada tahapan ini edukasi yang diberikan yaitu definisi nutrisi menurut ahli, tanda-tanda kekurangan gizi, penyebab kekurangan gizi, serta kandungan nutrisi beberapa tanaman seperti kangkung, bayam, selada dan sawi, serta cara pengolahan sayuran untuk menjaga kandungan nutrisinya. Tahapan ini dilaksakan pada tanggal 13 Juni 2021 di halaman Masjid Al-Furqan Kelurahan Minasaupa. Kegiatan dilaksanakan dengan tetap menerapkan protokol kesehatan di lokasi kegiatan. Adapun dokumentasi pemberian materi manajemen nutrisi yang dilaksanakan secara luring dapat dilihat pada gambar 3 .

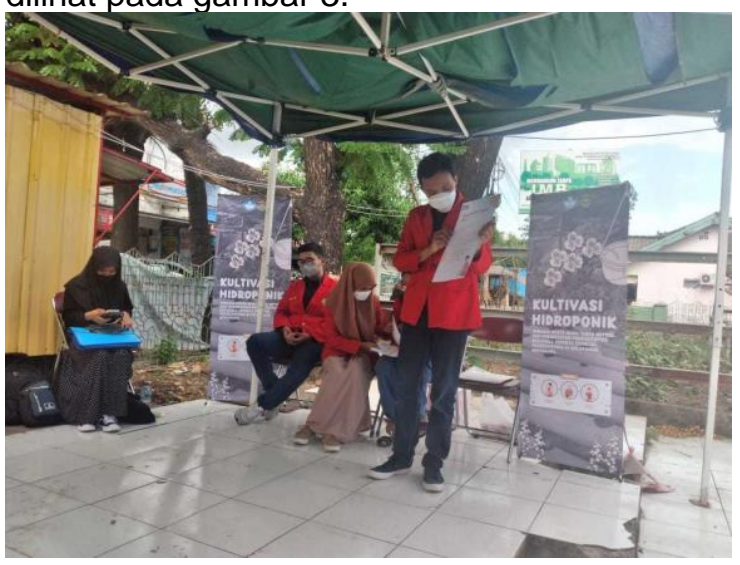

Gambar 3. Pemberian materi manajemen nutrisi (foto diambil sebelum penerapan PPKM)

Pada tahapan kelima juga diberikan tes kepada mitra pada awal dan akhir kegiatan yang bertujuan untuk mengetahui keberhasilan pemberian materi kepada mitra. Hasil dari kedua tes yang dapat dilihat pada tabel 1 , diketahui bahwa terdapat rata-rata peningkatan pengetahuan yang cukup signifikan pada mitra yaitu $44.186 \%$ dengan nilai absolut 25.333. 
Hasil pengolahan statistik juga membuktikan hampir semua mitra mengalami peningkatan pengetahuan, kecuali pada satu orang mitra. Hal ini mengindikasikan bahwa pemberian materi yang dilakukan sudah terbilang cukup efektif dan dapat meningkatkan pengetahuan mitra.

Tabel 1. Hasil Pre dan Post Test Materi Manajemen Nutrisi

\begin{tabular}{cccc}
\hline $\begin{array}{c}\text { Inisial } \\
\text { Mitra }\end{array}$ & $\begin{array}{c}\text { Hasil } \\
\text { Pre- } \\
\text { test }\end{array}$ & $\begin{array}{c}\text { Hasil } \\
\text { Post- } \\
\text { test }\end{array}$ & Kenaikan \\
\hline SW & 20 & 60 & $200 \%$ \\
\hline WA & 40 & 60 & $50 \%$ \\
\hline MA & 60 & 80 & $33.333 \%$ \\
\hline YU & 60 & 80 & $33.333 \%$ \\
\hline JU & 80 & 80 & $0 \%$ \\
\hline HA & 80 & 100 & $25 \%$ \\
\hline RA & 60 & 80 & $33.333 \%$ \\
\hline DI & 60 & 80 & $33.333 \%$ \\
\hline SO & 60 & 100 & $66.666 \%$ \\
\hline NT & 80 & 100 & $25 \%$ \\
\hline AA & 40 & 80 & $100 \%$ \\
\hline KA & 80 & 100 & $25 \%$ \\
\hline MI & 80 & 100 & $25 \%$ \\
\hline DP & 20 & 60 & $200 \%$ \\
\hline HA & 40 & 80 & $100 \%$ \\
\hline Rata-rata & 57.333 & 82.666 & $44.186 \%$ \\
\hline Tertinggi & 80 & 100 & \\
\hline Terendah & 20 & 60 & \\
\hline & \multicolumn{3}{l}{}
\end{tabular}

Pada tahapan keenam dilaksanakan edukasi kultivasi hidroponik, mencakup materi lengkap mengenai kultivasi hidroponik dan praktik langsungnya. Mitra menunjukkan antusiasmenya dalam mengikuti pengajaran dan praktik. Mitra juga telah mampu mempraktikkan secara mandiri cara penyemaian bibit hidroponik. Tahapan ini dilaksanakan pada tanggal 19 Juni 2021 di halaman Masjid Al-Furqan Kelurahan Minasaupa. Adapun dokumentasi pemberian edukasi kultivasi hidroponik yang mencakup materi dan praktiknya dapat dilihat pada gambar 4.

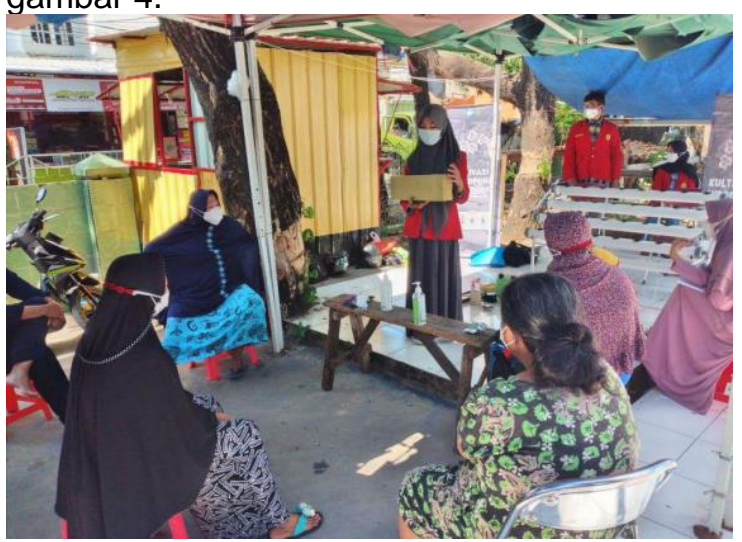

Gambar 4. Pemberian edukasi dan praktik kultivasi hidroponik (foto diambil sebelum penerapan PPKM)

Pada tahapan terakhir, tim melakukan pendampingan secara langsung kepada masyarakat mitra saat melaksanakan kultivasi hidroponik, mulai dari tahap penyemaian hingga tahap panen. Tahapan penyemaian, pindah tanam, dan monitoring ini dilaksanakan selama bulan Juni hingga Juli 2021 bertempat di BTN Minasa Upa blok N. Adapun dokumentasi pendampingan proses kultivasi hidroponik dapat dilihat pada gambar 5 .
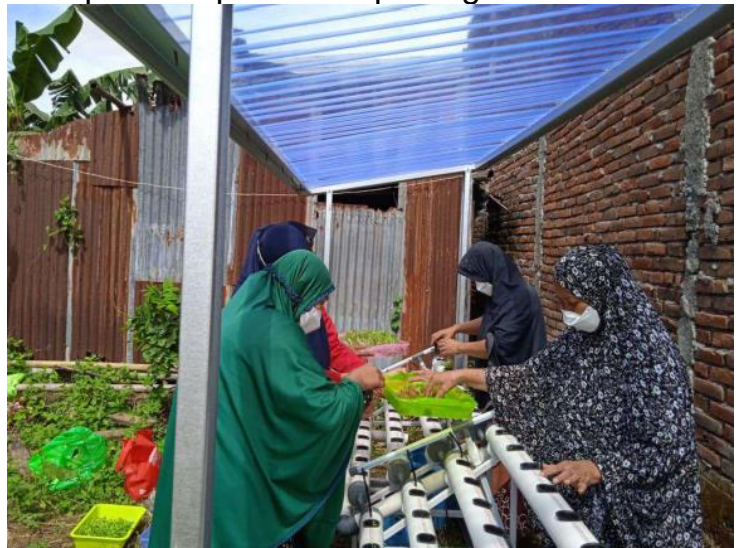

Gambar 5. Pendampingan proses kultivasi hidroponik.

Pelaksanaan pengabdian kultivasi hidroponik ini telah berhasil mencapai satu kali proses panen tanaman berupa kangkung dan sawi hidroponik. Adapun proses panen tanaman ini berlangsung pada tanggal $25 \mathrm{Juli}$ 2021 bertempat di BTN Minasa Upa blok N. Adapun dokumentasi proses panen tanaman hasil dari kultivasi hidroponik dapat dilihat pada gambar 6 .

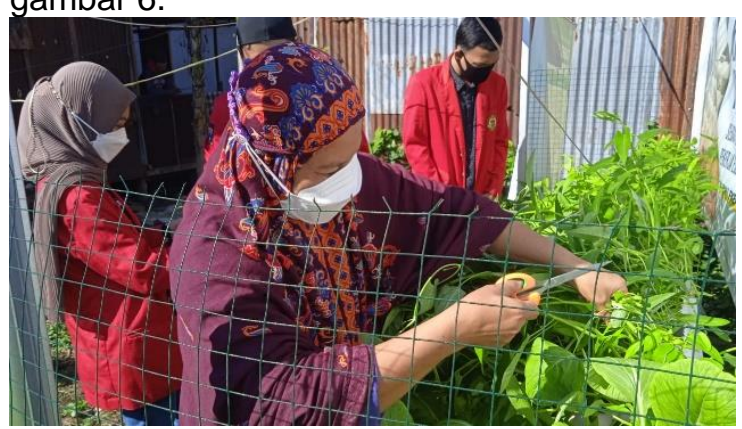

Gambar 6. Proses panen tanaman hidroponik

Adapun sayuran yang dipanen pada tahapan ini adalah kangkung dan sawi hijau. Menurut data dari USDA, per 100 gram kangkung mengandung kalori $18 \mathrm{kkal}$, tanpa kolestrol, jumlah lemak 0.2 gram, natrium 113 $\mathrm{mg}$, kalium $312 \mathrm{mg}$, jumlah karbohidrat 3.1 gram, serat pangan 2.1 gram, dan protein 2.6 gram. Sedangkan kandungan nutrisi pada sawi hijau dari data pangan KEMENKES RI per 100 
gramnya adalah kalori $20 \mathrm{kkal}$, protein $1.7 \mathrm{gram}$, lemak 0.4 gram, karbohidrat 3.4 gram, serat 1.2 gram, natrium $18 \mathrm{mg}$, dan kalsium $123 \mathrm{mg}$.

Selama proses pendampingan kultivasi hidroponik, kendala yang dihadapi adalah rendahnya tingkat pendidikan yang dimiliki masyarakat mitra, sebab kebanyakan masyarakat mitra hanya menyelesaikan pendidikan tingkat SMP maupun SMA. Hal ini pada akhirnya berdampak pada kemampuan masyarakat mitra dalam menerima edukasi yang diberikan. Selain itu, kebanyakan masyarakat mitra juga masih belum memiliki pengetahuan yang cukup mengenai hidroponik, sehingga perlu diberikan pemahaman dari tingkatan mendasar. Tapi pada akhirnya semua kendala ini dapat teratasi dengan antusiasme yang tinggi dari masyarakat mitra dalam menerima edukasi dan pendampingan. Pemateri juga terus berusaha menggunakan istilah-istilah yang mudah dimengerti oleh kalangan masyarakat awam.

\section{SIMPULAN DAN SARAN}

Masyarakat mitra menunjukkan antusiasme yang tinggi dalam menerima materi mulai dari pengantar kesehatan, manajemen nutrisi, hingga kultivasi hidroponik. Dari hasil evaluasi terlihat pula kenaikan yang cukup signifikan dari pengetahuan masyarakat mitra setelah menerima edukasi dari tim. Mitra juga telah mampu mempraktikkan tahapan-tahapan kultivasi hidroponik mulai dari penyemaian, pindah tanam, hingga panen, hal ini terbukti dari keberhasilan mitra memanen hasil kultivasi hidroponiknya dalam jangka waktu satu bulan. Selanjutnya saran untuk kegiatan pengabdian masyarakat lainnya yang ingin mengambil topik serupa, sebaikntya dalam memberikan edukasi kepada masyarakat, sebaiknya menggunakan istilah-istilah yang dapat dimengerti oleh kalangan masyarakat awam. Selain itu, saat berhadapan dengan masyarakat, perlu diberi kegiatan-kegiatan selingan yang dapat meningkatkan semangat masyarakat dalam menerima edukasi dan pendampingan, sebab hal tersebut dapat meningkatkan antusiasme masyarakat mitra dalam menerima materi.

\section{UCAPAN TERIMAKASIH}

Ucapan terimakasih disampaikan kepada Kementrian Pendidikan, Kebudayaan, Riset, dan Teknologi, Direktorat Jenderal Pendidikan Tinggi yang telah memberikan pembiayaan untuk pengabdian ini, melalui Program Kreativitas Mahasiswa (PKM) Pengabdian kepada Masyarakat tahun 2021.

Tim juga mengucapkan terimakasih kepada Ns. Wa Ode Nur Isnah sebagai dosen pendamping pelaksanaan PKM ini, Ns. Arnis
Puspitha sebagai praktisi hidroponik yang telah banyak membantu dalam proses kultivasi hidroponik, Ibu Yuli sebagai ketua masyarakat mitra, dan seluruh masyarakat mitra yang telah mendukung kelancaran kegiatan ini.

\section{DAFTAR RUJUKAN}

Hidayati, D., Suyatno, Aruben, R., \& Pradigo, S. F. (2017). Faktor Risiko Kurang Konsumsi Buah Dan Sayur Pada Anak Usia Sekolah Dasar (Studi Kasus-Kontrol Pada Siswa SDN Sendangmulyo 03 Semarang Tahun 2017). Jurnal Kesehatan Masyarakat (eJournal), 5(4), 638-647.

Masduki, A. (2018). Hidroponik Sebagai Sarana Pemanfaatan Lahan Sempit Di Dusun Randubelang, Bangunharjo, Sewon, Bantul. Jurnal Pemberdayaan: Publikasi Hasil Pengabdian Kepada Masyarakat, 1(2), 185. https://doi.org/10.12928/jp.v1i2.317

Nurlaili, Habibah, U., Fakhriza, F., Jannifar, A., \& Muslim. (2019). Budidaya Sayuran Yang Murah Dan Sederhana Dengan Metode Hidroponik Di Desa Jambo Timu Kecamatan Blang Mangat Kota Lhokseumawe Provinsi Aceh. Jurnal Vokasi, 3(2), 106. https://doi.org/10.30811/vokasi.v3i2.1462

Putri, D. P. K., \& Lestari, S. (2015). Pembagian Peran Dalam Rumah Tangga Pada Pasangan Suami Istri Jawa. Jurnal Penelitian Humaniora, 16(1), 72-85.

Zubaidi, N., Pratama, R. G., \& Al-Fatih, S. (2020). Legal Perspective on Effectiveness of Pre-Work Cards for Indonesian People. Jurnal Bestuur, 8(1), 9-18.

https://doi.org/10.20961/bestuur.v8i1.427 22 